\title{
PENGENDALIAN EMOSI PADA REMAJA PELAKU TINDAK KRIMINAL DI LEMBAGA PEMASYARAKATAN KHUSUS ANAK (LPKA) BANDUNG
}

\author{
Oleh: \\ Theresia Vania Radhitya $\mathbf{W}^{\mathbf{1}}$, Meilanny Budiarti Santoso ${ }^{2}$ \\ ${ }^{1}$ Mahasiswa Kesejahteran Sosial, Fakultas Ilmu Sosial dan Ilmu Politik, Universitas Padjadjaran \\ ${ }^{2}$ Departemen Kesejahteraan Sosial, Fakultas Ilmu Sosial dan Ilmu Politik, Universitas Padjadjaran \\ E-mail: theresia.vania@gmail.com dan meilannybudiarti13@gmail.com
}

\begin{abstract}
Abstrak
Masa remaja merupakan masa yang rentan pada perkembangan diri manusia. Perubahan fisik, kognitif, dan psikososial terjadi di masa ini. Di masa inilah seorang individu memiliki banyak permasalahan. Situasi inipun dirasakan oleh seorang remaja yang saat ini menjalankan kehidupannya di LPKA karena harus berhadapan dengan hukum. Remaja yang berhadapan dengan hukum akan memiliki permasalahan yang lebih kompleks jika dibandingkan dengan remaja biasanya. Tekanan yang diterima pun lebih besar sehingga akan membuat dirinya terlalu overthinking terhadap sesuatu dan membuat perubahan emosi yang terkadang sulit dikendalikan. Hal ini dirasakan oleh klien yang dimana mengalami kesulitan dalam mengendalikan emosi sehingga memberikan dampak negatif bagi dirinya sendiri dan lingkungan sekitarnya. Dengan begitu fokus pembahasan dalam artikel ini adalah bagaimana membantu seorang remaja agar dapat mengendalikan emosi. Klien yang sulit mengendalikan emosi dapat dibantu oleh praktikkan untuk dapat mengendalikan emosinya. Praktikkan membantu dengan membangun hubungan antara praktikkan dan klien sehingga menumbuhkan kepercayaan klien. Praktikkan menawarkan beberapa metode yang berkaitan dan metode yang disepakati untuk digunakan adalah metode Cognitive Restructuring Form dan Deep Breathing. Proses intervensi menggunakan metode ini dilakukan selama dua minggu. Dari proses intervensi yang dilakukan selama dua minggu itu maka didapatkan hasil bahwa klien sudah mulai dapat mengendalikan emosi dengan baik. Klien juga sudah bisa berpikir secara positif namun masih belum terbiasa menggunakan pikiran tersebut. Hasil tersebut dapat dipertanggungjawabkan dengan tabel yang ada pada artikel ini.
\end{abstract}

Kata kunci: terapi kognitif, pengendalian emosi, deep breathing, cognitive restructuring form, remaja

\begin{abstract}
Adolescence is a period that is vulnerable to human development. Physical, cognitive, and psychosocial changes occur in this period. At this time an individual has many problems. Even this situation is felt by a teenager who is currently running his life in LPKA because he has to deal with the law. Adolescents who are faced with the law will have more complex problems compared to normal teens. The pressure received is even greater so that it will make him too overthinking something and make emotional changes that are sometimes difficult to control. This is felt by clients who experience difficulty in controlling emotions so that it has a negative impact on themselves and the surrounding environment. That way the focus of the discussion in this article is how to help a teenager to control emotions. Clients who have difficulty controlling emotions can be helped by practicing to be able to control their emotions. Practice helps by building relationships between practice and clients so as to foster client trust. Practice offers several related methods and the method agreed to be used is the Cognitive Restructuring Form and Deep Breathing method. The intervention process using this method was carried out for two weeks. From the intervention process carried out for two weeks, it was found that the client had begun to be able to control emotions well. Clients also have been able to think positively but are still not used to using these thoughts. These results can be accounted for with the table in this article.
\end{abstract}

Keyword(s): cognitive therapy, emotional control, deep breathing, cognitive restructuring form, adolescence. 


\section{PENDAHULUAN}

Masa remaja seringkali disebut masa yang paling rentan. Masa remaja dapat didefinisikan sebagai masa transisi dari masa anak-anak menuju dewasa. Pada masa ini remaja mengalami banyak perubahan mulai dari perubahan fisik, kognitif, dan psikososial. Di masa ini remaja memiliki energi yang besar, emosi yang berkobar-kobar dan kondisi mereka seringkali belum mampu mengendalikan diri.

Artikel ini disusun berdasarkan data yang diperoleh penulis saat melakukan kegiatan praktikum pekerjaan sosial dengan individu dan pengembangan diri. Praktikan saat itu bekerja bersama klien seorang remaja laki-laki berumur 17 tahun.

Klien saat ini sedang menjalani kehidupannya di LPKA Bandung dikarenakan pernah melakukan tindak kriminal memiliki permasalahan yang lebih kompleks jika dibandingkan dengan remaja biasa lainnya. Klien sebagai anak yang berhadapan dengan hukum dan saat ini harus menjalani hukuman untuk mempertanggungjawabkan perilakunya membuat tekanan hidup yang diterima tinggi terlebih disaat seperti ini klien merasa jauh dari orang terdekatnya. Dengan begitu permasalahan yang dialami klien sangat banyak.

Klien memiliki beberapa permasalah dalam dirinya salah satunya adalah dalam mengendalikan emosi. Klien mengaku seringkali emosi pada halhal kecil yang sebenarnya tidak perlu dihadapi dengan sikap emosional. Misalkan saja, saat klien merasa badmood karena harus tetap membereskan tempat tidur, padahal klien merasa sangat malas untuk melakukannya.

Klien juga mengaku tidak dapat mengendalikan emosi saat orang-orang terdekatnya seperti keluarga atau sahabatnya disakiti oleh orang lain. Klien merasa bahwa ia harus bisa melawan orang yang menyakiti keluarga atau sahabatnya itu, sehingga terkadang klien memakai kekerasan untuk melakukan perlawanan. Klien merasa bahwa dirinya merupakan seorang yang emosional dan hal tersebut menjadi hambatan yang berpengaruh negatif dalam kehidupannya sehari-hari. Walapun demikian, klien pun percaya ada kelebihan pada dirinya yang dapat digunakan untuk melawan emosinya. Dengan demikian, dalam kegiatan praktikum pekerjaan sosial dengan individu dan pengembangan diri ini, praktikan melakukan proses intervensi untuk membantu klien dalam menghadapi kondisi ini dengan memberikan terapi kognitif.

\section{Masa Remaja: Masa Rentan dan Masa Perkembangan Kognitif}

Muss (1968) dalam Sarwono (2011: 11) $)^{1}$ menyatakan bahwa remaja (adolescence) berasal dari kata adolescere (Bahasa Latin) memiliki arti tumbuh ke arah kematangan. Kematangan ini meliputi kematangan fisik, sosial-psikologis. Remaja memiliki tugas perkembangan, menurut Havighurst dalam Hurlock (1990) ${ }^{2}$, tugas perkembangan remaja meliputi: (1) Mencapai pola hubungan baru yang lebih matang dengan teman sebaya yang berbeda jenis kelamin sesuai dengan keyakinan dan etika moral yang berlaku di masyarakat; (2) Mencapai peranan sosial sesuai dengan jenis kelamin, selaras dengan tuntutan sosial dan kultural masyarakat; (3) Menerima kesatuan organ-organ tubuh/keadaan fisiknya sebagai pria/wanita dan menggunakannya secara efektif sesuai dengan kodrat masing-masing; (4) Menerima dan mencapai tingkah laku sosial tertentu yang bertanggung jawab di tengah masyarakat; (5) Mencapai kebebasan emosional dari orang tua dan orang dewasa lainnya dan mulai menjadi "diri sendiri"; (6) Mempersiapkan diri untuk mencapai karir (jabatan dan profesi) dalam bidang kehidupan ekonomi; (7) Mempersiapkan diri untuk memasuki dunia perkawinan dan kehidupan berkeluarga; (8) Memperoleh seperangkat nilai dan sistem etika sebagai pedoman bertingkah laku dan mengembangkan ideologi untuk keperluan kehidupan kewarganegaraannya.

Menurut Hall dalam Sarwono (2011) ${ }^{3}$, masa remaja merupakan masa "storm and drang" di masa ini penuh emosi dan kerapkali emosi meledak-ledak karena ada pertentangan nilai. Dengan begitu masa remaja kerap kali dikatakan masa yang rentan. Menurut McWhirter et al. $(2007)^{4}$, kerentanan terjadi sepanjang rangkaian risiko kecil hingga risiko besar. Perilaku yang tergolong rentan memiliki rentang mulai dari

\footnotetext{
${ }^{1}$ Sarwono, Psikologi Remaja, (Jakarta: PT. Rajawali Pers, 2011), hlm.11.

${ }^{2}$ Hurlock, Psikologi Perkembangan Suatu Rentan Kehidupan, (Jakarta: Erlangga, 1990).

${ }^{3}$ Sarwono, Psikologi Remaja, (Jakarta: PT. Rajawali Pers, 2011.

${ }^{4}$ McWhirter, At Risk Youth: A Comprehensive Response for Counselors, teachers, Psychologists, and Human Service Professionals, (United States of America: Thomson Brooks/Cole, 2007).
} 
penolakan sosial sampai masalah terjadi di sekolah, melalui aktivitas yang melanggar nilai dan norma (membolos, menggunakan narkoba) hingga hal-hal illegal secara hukum (tawuran, pencurian, pemerkosaan, pemukulan).

Selain itu, di masa remaja juga terjadi perkembangan kognitif. Menurut Piaget dalam

b. kesempatan untuk melakukan penalaran deduktif hipotesis dan berpikir proporsional. Penalaran deduktif hipotesis merupakan proses kognitif di mana seseorang dihadapkan pada permasalahan akan memulai dengan "teori umum" dari seluruh faktor yang memungkingkan memberi pengaruh pada hasil dan menyimpulkan dalam suatu prediksi.

c. Memahami kebutuhan logis dari pemikiran proporsional, memperbolehkan penalaran tentang alasan kontradiktif dengan realita. Remaja bisa mengevaluasi logika dari pernyataan verbal tanpa merujuk keadaan dunia nyata.

d. Memperlihatkan distorsi kognitif yang secara bertahap akan menurun dan menghilang di usia dewasa. Remaja akan mulai berpikir lebih tentang dirinya sendiri. Piaget meyakini bahwa pada masa remaja telah terbentuk egosentrisme baru pada tahap operasi formal, yaitu muncul ketidakmampuan untuk membedakan perspektif abstrak dari diri sendiri dan orang lain (Inhelder \& Piaget, 1955/1958, dalam Berk, 2003) ${ }^{5}$.

\section{Emosi Pada Remaja}

Menurut Asrori (2005: 105) ${ }^{6}$, masa remaja beserta karakteristik emosi dapat di bagi ke dalam empat periode, yaitu:

a. Periode Pra-Remaja

Gerakan-gerakan yang dilakukan remaja mulai kaku dalam periode ini. Perubahan ini disertai sifat kepekaan terhadap rangsangan-rangsangan dari luar dan respon berlebih, sehingga mudah tersinggung dan cengeng, cepat merasa senang atau meledakledak.

\footnotetext{
${ }^{5}$ Berk, Child Development, (Boston: Allyn and Bacon, 2003).

${ }^{6}$ Ali \& Asrori, Psikologi Remaja Perkembangan Peserta Didik, (PT. Bumi Aksara, 2005), hlm. 105.
}

Berk (2003: 244-249) beberapa ciri dari perkembangan kognitif di masa remaja mengacu pada teori perkembangan kognitif antara lain:

a. Mampu menalar secara abstrak dalam situasi yang menawarkan beberapa

b. Periode Remaja Awal

Remaja cenderung menyendiri, sehingga merasa terasingkan, kurang perhatian dari orang lain, dan tidak ada orang yang mulai mempedulikannya. Kontrol bertambah sulit dan cepat marah dengan cara yang kurang wajar.

c. Periode Remaja Tengah

Terjadi peningkatan tanggung jawab dari orang tua, keluarga hingga masyarakat. Masyarakat sering menunjukkan kontradiksi dengan nilai moral yang diketahui, dengan begitu remaja mulai ragu mengenai hal-hal yang dianggap baik dan buruk. Oleh karena itu, remaja dalam tahap ini membentuk nilai yang dianggap benar, baik, dan pantas dikembangkan pada diri mereka sendiri.

d. Periode Remaja Akhir

Remaja memandang dirinya sebagai orang dewasa dan mampu menunjukkan pemikiran, sikap, dan perilaku yang semakin dewasa. Remaja dalam tahap ini mampu mengendalikan emosi dan emosinya stabil serta sudah lebih bijaksana dalam mengambil pilihan atau keputusan.

Menurut Ali \& Ansori (2005) dan Nursalim $(2013)^{7}$, terdapat beberapa faktor yang mempengaruhi emosi remaja, yaitu:

a. Perubahan jasmani

Pada masa remaja terjadi pertumbuhan yang sangat cepat pada anggota tubuh, sehingga menjadikannya tidak seimbang. Kondisi ketidakseimbangan dalam tubuh ini berpengaruh terhadap perkembangan emosi remaja karena beberapa remaja tidak dapat menerima perubahan pada kondisi tubuhnya. Selain itu, hormon tertentu sudah berfungsi pada tubuh remaja,

\footnotetext{
${ }^{7}$ Nursalim, Strategi Intervensi dan Konseling, (Jakarta: Indeks, 2013).
} 
sehingga dapat menyebabkan rangsangan dalam tubuh dan menimbulkan masalah dalam perkembangan emosi.

b. Perubahan Pola Interaksi dengan Orang Tua

Perbedaan pola asuh orang tua berpengaruh pada perkembangan emosi remaja. Pemberontakan remaja pada orang tua menunjukkan keinginan mereka untuk melepaskan diri dari pengawasan orang tua. Perlawanan ini membuat remaja puas dalam menunjukkan bahwa dirinya berhasil menjadi orang yang sudah dewasa. Jika remaja berhasil melawan orang tua, hingga orang tua menjadi marah, hal ini membuat remaja merasa belum puas karena orang tua tidak menunjukkan pengertian yang diinginkan, sehingga keadaan ini mempengaruhi perkembangan emosi remaja.

c. Perubahan Interaksi dengan Teman Sebaya

Remaja membangun interaksi dengan teman sebaya secara khusus untuk melakukan aktivitas bersama yang bisa dikatakan membentuk geng. Hubungan antaranggota dalam suatu geng biasanya bersifat intens, memiliki kohesivitas dan solidaritas yang tinggi. Pada masa ini sebaiknya geng dapat mempengaruhi individu ke arah yang lebih positif. Biasanya anggota dalam geng membutuhkan teman untuk melawan otoritas atau perbuatan yang tidak baik bahkan kejahatan bersama.

d. Perubahan Pandangan Luar

Perubahan pandangan dunia luar juga menjadi faktor penting yang mempengaruhi perkembangan emosi pada remaja. Beberapa perubahan mengenai pandangan dunia luar dapat menyebabkan konflik emosional dalam diri remaja. Kerapkali remaja dianggap sudah dewasa, akan tetapi mereka tidak mendapatkan kebebasan penuh sebagaimana yang dilakukan orang dewasa. Mereka masih sering dianggap sebagai anak kecil yang kerapkali membuat mereka jengkel. Dari kejengkelan itulah kemudian menimbulkan tingkah laku emosional pada remaja.

\section{Cognitive Restructing Form}

Teknik cognitive resturucting menurut Ellis (dalam Nursalim, 2013: 32$)^{8}$ yaitu memusatkan perhatian pada upaya mengidentifikasi dan mengubah pikiran atau pernyataan diri negatif serta keyakinan klien yang tidak rasional menjadi pikiran positif dan rasional. Teknik ini dirancang untuk membantu mencapai respon emosional yang baru dan lebih baik dengan mengubah kebiasaan penilaian habitual (kebiasaan) yang biasa digunakan, sehingga menjadi tidak terlalu bias (Dombeck \& Wells-Moran, 2014 dalam Efrod 2017:255) ${ }^{9}$.

Cognitive Resturucturing Form (CRF) merupakan salah satu metode dalam pekerja sosial dalam mengatasi masalah klien terkait dengan kondisi cognitive mereka. Form ini berperan untuk membiasakan klien yang seringkali otomatis berpikiran negatif pada beberapa kejadian yang tidak diinginkan untuk mencari pikiran alternatif yang positif. Apabila klien sudah membiasakan diri mengisi form ini, maka klien akan mampu mengubah pikiran negatif dengan alternatif pikiran positif secara otomatis saat mereka menghadapi kejadian yang mengganggu.

Dalam menggunakan Cognitive Resturucturing Form (CRF), langkah-langkah yang dilakukan kepada klien adalah sebagai berikut:

a. Memberitahukan maksud dan tujuan pemberian CRF kepada klien. Hal ini dilakukan karena klien harus mengetahui maksud dan tujuan dari diberikannya $C R F$, sehingga mereka mau terlibat dalam proses intervensi.

b. Memberi tahu langkah-langkah mengisi kolom yang ada di dalam $C R F$. Hal ini dilakukan dengan memberi beberapa contoh situasi atau kejadian yang dapat menimbulkan emosi pada diri klien.

c. Meminta klien menentukan pikiran otomatis negatif yang dimilikinya saat kejadian tersebut terjadi. Lalu meminta klien untuk memberi presentase nilai pada emosi yang dirasakannya tersebut.

d. Mendiskusikan hal yang harus dipikirkan oleh klien mengenai kejadian tersebut. Apabila klien mengatakan hal yang tidak seharusnya

\footnotetext{
${ }^{8}$ Nursalim, Strategi Intervensi dan Konseling, (Jakarta: Indeks, 2013), hlm. 32.

${ }^{9}$ Efrod, 40 Teknik Yang Harus Diketahui Setiap

Konselor, (Yogyakarta: Pustaka Pelajar, 2017), hlm.255.
} 


\begin{tabular}{|c|c|c|c|c|}
\hline $\begin{array}{c}\text { Focus: Jurnal } \\
\text { Pekerjaan Sosial }\end{array}$ & ISSN: $2620-3367$ & Vol. 2 No: 2 & Hal: $219-231$ & Desember 2019 \\
\hline
\end{tabular}

mereka pikirkan (masih berupa pikiran negatif), maka praktikan berperan untuk mengarahkan klien pada pikiran positif yang kemudian harus dituliskan oleh klien pada kolom sangkalan terhadap pikiran negatif. Setelah itu, klien diminta untuk menuliskan presentase emosi yang baru tersebut.

e. Setelah klien mengetahui cara kerja penggunaan CRF, maka klien ditugaskan dalam kurun waktu 2 minggu untuk mengisi form tersebut secara mandiri.

Contoh dari Cognitive Restructuring Form (CRF) adalah seperti yang tertuang dalam tabel 1 berikut ini:

Tabel 1

Cognitive Restructing Form 6 kolom

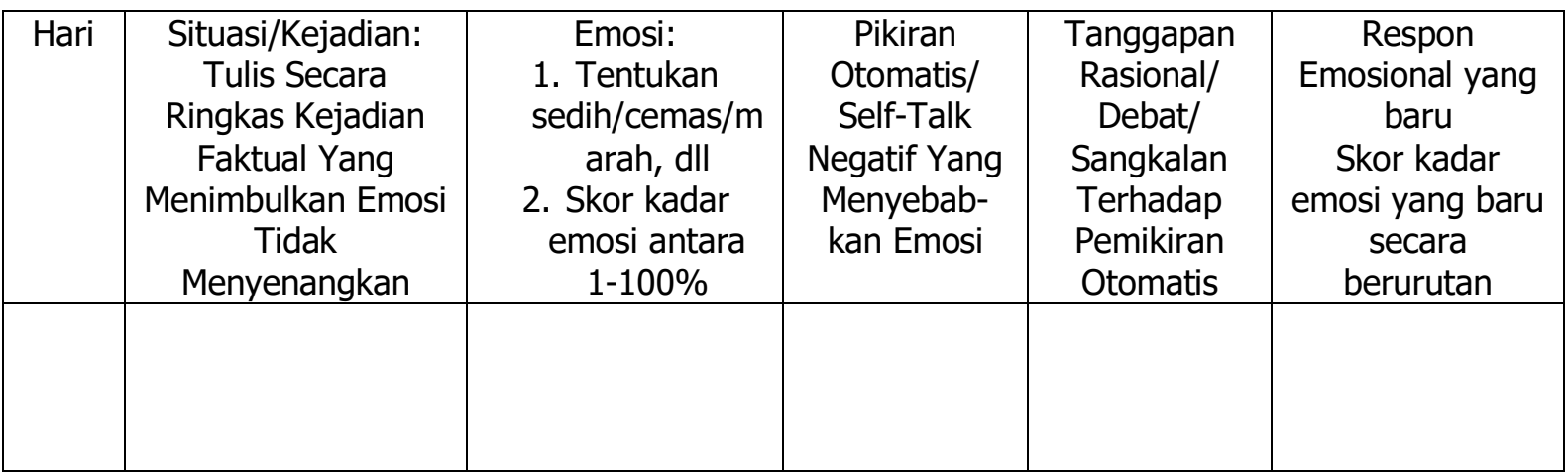

Sumber: Praktikum Pekerjaan Sosial dengan Individu dan

Pengembangan Diri, 2019

\section{Teknik Deep Breathing}

Teknik deep breathing merupakan salah satu Teknik yang dapat digunakan dalam praktik pekerjaan sosial. Teknik deep breathing merupakan salah satu terapi relaksasi yang dapat digunakan untuk menurunkan kadar emosi yang dialami oleh klien. Berikut ini merupakan langkahlangkah untuk melakukan teknik deep breathing, yaitu:

a. Duduk dengan senyaman mungkin dan rileks.

b. Mata dipejamkan lalu ambil nafas yang dalam secara perlahan melalui mulut.

c. Buang udara secara perlahan melalui mulut.

d. Ulangi langkah-langkah tersebut beberapa kali.

e. Rasakan gesekan udara di hidung, dengarkan suara paru-paru bergesekan dengan permukaan mulut.

f. Fokus, abaikan suara-suara yang mengganggu dan tetap fokus pada suara nafas sendiri yang terdengar.

g. Setelah itu, bukalah mata.
Teknik ini dilakukan untuk memberikan ketenangan pikiran dan jiwa klien, keberhasilan teknik ini ditentukan oleh seberapa rileks diri klien saat melakukannya.

\section{METODE}

Metode yang digunakan adalah metodologi andragogi yang mensyaratkan klien diposisikan sebagai orang dewasa dan didorong untuk berperan aktif dalam setiap tahapan kegiatan. Baik melalui teknik brainstrorming guna mengungkap berbagai permasalahan yang dihadapi remaja dan juga teknik sharing pengalaman diantara sesama peserta pelatihan dan juga fasilitator pelatihan. Hal ini bertujuan agar peserta pelatihan dapat melihat segala sesuatu yang terkait dengan permasalahan yang sedang dihadapi dari sudut pandang yang berbeda, hingga menemukan sudut pandang baru yang lebih positif dan dapat mengubah cara berpikir dan berperilaku mereka di kemudian hari. 
Focus: Jurnal

Pekerjaan Sosial

\section{HASIL DAN PEMBAHASAN}

\section{Hasil Assessment}

Kegiatan assessment yang dilakukan oleh praktikan merupakan tahapan awal kegiatan yang ditujukan untuk menggali dan mengetahui segala informasi/data terkait diri klien, lingkungan sosial di mana klien berada, potensi yang dimiliki oleh klien dan permasalahan yang sedang dihadapi oleh klien. Tahap assessment ini sangat penting untuk dilakukan dengan benar, karena dengan mengetahui informasi/data terkait keberadaan diri klien, maka praktikan dapat menganalisis dan kemudian bersama klien menentukan apakah klien perlu dibantu dalam mencari solusi dari permasalahan yang dihadapinya ataukah kegiatan pendampingan yang dilakukan oleh praktikan akan ditujukan untuk mendukung klien dalam mengoptimalkan potensi yang dimilikinya.

Di awal pertemuan, praktikan dan klien saling berkenalan dan bercerita satu sama lain. Praktikan mengemukakan maksud dan tujuan dari kegiatan praktikum yang sedang dilakukan kepada klien. Impresi yang praktikan dapatkan dari klien saat itu adalah klien cukup antusias dan mau terlibat dalam kegiatan yang sedang dilakukan.
Kemudian dalam pertemuan itu klien memperkenalkan dirinya bahwa dirinya bernama $T$ berusia 17 tahun. Sebagai seorang remaja laki-laki, klien senang bermain sepak bola dan mendaki gunung. Di awal pertemuan dengan praktikan, klien sudah dapat bersikap terbuka mengenai dirinya, salah satunya dengan mengatakan bahwa klien adalah seorang yang emosional. Dengan kondisi emosinya yang sangat mudah meledakledak, klien merasa hal tersebut menjadi penghambat bagi dirinya dalam melakukan beberapa aktivitas, terutama saat beraktivitas dengan orang lain.

Dalam tahapan assessment ini, praktikan mulai mengidentifikasi kelebihan dan kekurangan yang dimiliki oleh klien. Hal ini dilakukan untuk mengetahui dan menggali berbagai potensi yang dimiliki oleh klien dan untuk mengidentifikasi berbagai permasalahan yang dihadapi oleh klien.

Berdasarkan hasil assessment yang dilakukan, berikut ini teridentifikasi berbagai kelebihan, kekurangan, permasalahan dan aspek pribadi yang ingin dikembangkan oleh diri klien, yaitu seperti yang tertuang dalam tabel 2 berikut ini:

Tabel 2

Identifikasi Klien

\begin{tabular}{|c|c|c|c|c|}
\hline Nama & Kelebihan & Kekurangan & Masalah & $\begin{array}{lr}\text { Aspek } & \text { Pribadi } \\
\text { yang } & \text { ingin } \\
\text { dikembangkan }\end{array}$ \\
\hline$T$ & $\begin{array}{l}\text { 1. } \text { Memiliki } \\
\text { solidaritas } \\
\text { tinggi } \\
\text { terhadap } \\
\text { teman. } \\
\text { 2. Mudah } \\
\text { beradaptasi. } \\
\text { 3. Keterampilan } \\
\text { dalam } \\
\text { bermain bola. }\end{array}$ & $\begin{array}{l}\text { 1. Emosional } \\
\text { 2. Malas } \\
\text { 3. Mudah } \\
\text { terenyuh jika } \\
\text { ada sesuatu } \\
\text { hal terkait } \\
\text { orang tua }\end{array}$ & $\begin{array}{l}\text { 1. Sering emosi } \\
\text { pada hal kecil. } \\
\text { 2. Malas } \\
\text { membereskan } \\
\text { tempat tidur } \\
\text { padahal wajib } \\
\text { untuk dilakukan, } \\
\text { sehingga hampir } \\
\text { setiap bangun } \\
\text { pagi menjadi } \\
\text { emosi }\end{array}$ & $\begin{array}{l}\text { 1. Tidak mudah } \\
\text { marah. } \\
\text { 2. Tidak malas } \\
\text { membereskan } \\
\text { tempat tidur, } \\
\text { sehingga tidak } \\
\text { emosi di pagi } \\
\text { hari }\end{array}$ \\
\hline
\end{tabular}

Sumber: Praktikum Pekerjaan Sosial dengan Individu dan

Pengembangan Diri, 2019

Berdasarkan data yang tertuang pada tabel 2 tersebut, maka teridentifikasi bahwa klien mengalami masalah pengendalian emosi. Hal ini seperti yang secara langsung telah diungkapkan oleh klien kepada praktikan pada saat awal pertemuan assessment.

Setelah praktikan mengetahui kelebihan, kekurangan, masalah yang sedang klien hadapi 


\begin{tabular}{|c|c|c|c|c|}
\hline $\begin{array}{c}\text { Focus: Jurnal } \\
\text { Pekerjaan Sosial }\end{array}$ & ISSN: $2620-3367$ & Vol. 2 No: 2 & Hal: $219-231$ & Desember 2019 \\
\hline
\end{tabular}

dan perubahan yang diinginkan oleh klien, selanjutnya praktikan menggali informasi/data terkait keberadaan keluarga klien, yang dituangkan dalam genogram keluarga klien, seperti yang terlihat dalam gambar 1 berikut ini:

Gambar 1

Genogram Klien

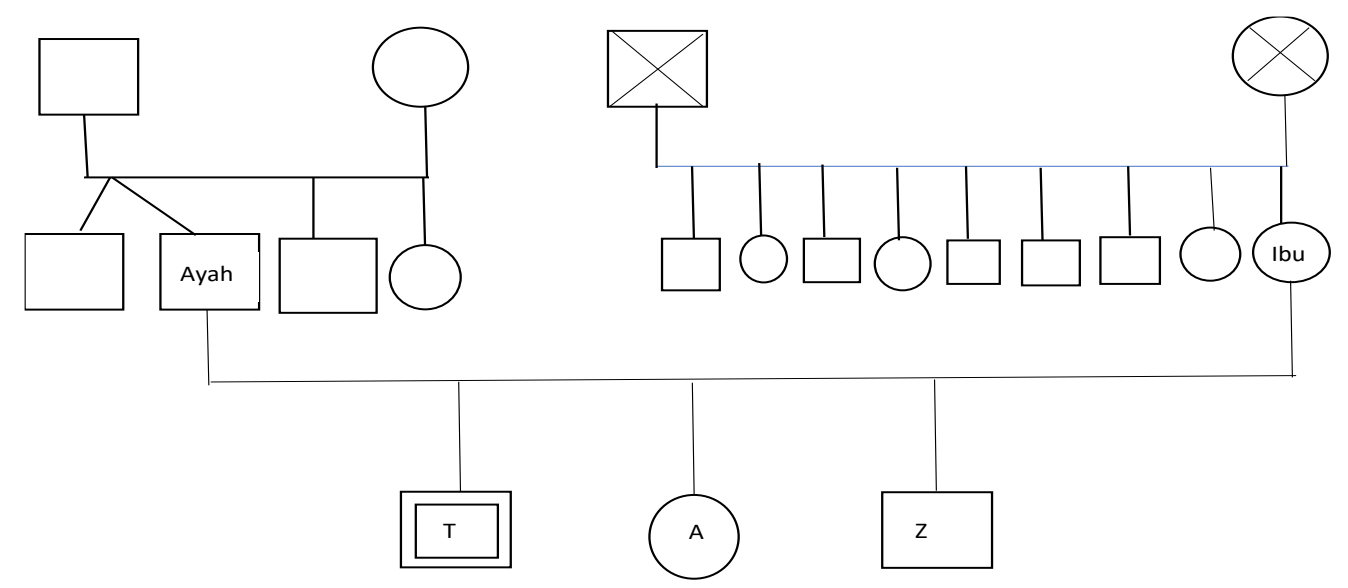

Keteranean :

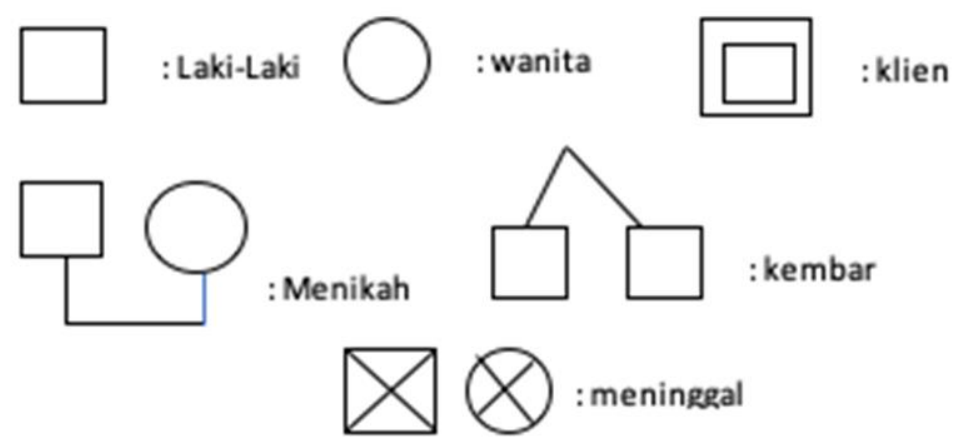

Sumber: Praktikum Pekerjaan Sosial dengan Individu dan Pengembangan Diri, 2019

Berdasarkan genogram yang dibuat oleh klien, tampak bahwa hubungan keluarga yang dimiliki klien adalah sebagai berikut: Klien $(T)$ seorang remaja laki-laki berusia 17 tahun yang merupakan anak pertama dari tiga bersaudara. Klien berasal dari daerah Rancaekek Kabupaten Bandung. Namun, saat ini klien tinggal di Lembaga Pembinaan Khusus Anak (LPKA) Bandung.

Klien memiliki dua orang adik, yaitu A dan Z. A merupakan adik perempuan klien yang berusia 12 tahun dan $\mathrm{Z}$ merupakan adik laki-laki klien yang saat ini berusia 4 tahun. Ayah klien saat ini berumur 36 tahun, bekerja sebagai penjual buku keliling ke sekolah-sekolah. Saat ini ibu klien berumur 32 tahun, sebagai seorang ibu rumah tangga. Orang tua dari ibu klien keduanya sudah meninggal.

Klien mengaku hubungannya dengan keluarga baik-baik saja. Ayah klien memiliki saudara kembar dan dua orang adik yang berjenis kelamin laki-laki dan perempuan. Ibu klien merupakan anak bungsu dari 9 bersaudara. Klien cukup dekat dengan keluarga besarnya dikarenakan rumah mereka masih dekat dengan rumah klien. Dari penuturan klien, klien lebih dekat dengan adik perempuan ayahnya jika dibandingkan saudara ayahnya yang lain dikarenakan umur mereka sama. Hubungan klien 
dengan ayahnya juga cukup baik. Klien sering berdiskusi tentang olah raga dengan ayahnya. Hubungan klien dengan ibunya sangatlah dekat, klien mengaku bahwa ibunya merupakan tempat klien mencurahkan isi hatinya ketika klien merasa senang ataupun sedih. Kedua orang tua klien mendukung dan tidak pernah meninggalkan klien saat sedang kesusahan.

Klien pun menceritakan perjuangan kedua orang tuanya selama ini yang selalu ikut menemani klien saat persidangan dan sudah banyak pengorbanannya dalam menemani dan mendukung klien saat persidangan. Orang tuanya juga masih sering mengunjungi klien di LPKA.

Sebelum masuk LPKA, ada suatu kejadian di mana klien merasa kecewa terhadap orang tuanya hingga klien kabur dari rumah selama 2 hari ke rumah uwanya dan uwanya tidak memberitahukan keberadaan klien kepada orang tuanya. Alasan kekesalan klien pada orang tuanya adalah karena saat itu klien ingin sekali mengikuti seleksi timnas, namun karena biaya pendaftaraan yang terlalu mahal, yaitu sebesar 10 juta rupiah, orang tua klien tidak dapat memberikan uang pendaftaran tersebut. Namun, ternyata kemudian klien mengetahui bahwa setelah kejadian itu, orang tuanya malah membeli perlengkapan rumah tangga dan alat elektronik lainnya, sehingga membuat klien menjadi marah dan kecewa pada orang tuanya.

Sekarang, hubungan klien dengan orang tuanya sudah membaik. Keluarga klien tidak ada yang menjelek-jelekkan klien, melainkan mereka tetap mendukung klien. Hubungan klien dengan adiknya pun cukup dekat. Namun klien mengaku terkadang sering bertengkar dengan adik perempuannya mengenai masalah waktu bermain. Klien tidak suka adik perempuannya pulang malam, menurutnya adiknya tersebut tidak tahu waktu saat bermain yang seharusnya anak perempuan sudah di rumah saat malam.

Klien lebih dekat dengan adik laki-lakinya, mereka berdua sering bermain bersama. Komunikasi keluarga klien bisa dikatakan cukup baik karena mereka masih menyempatkan waktu untuk sarapan bersama, sehingga bisa saling bercerita mengenai apa yang mereka alami.

Dalam keluarga besarnya klien mengaku cukup dekat dengan kakek dan neneknya serta beberapa anggota keluarga dari ayah dan ibunya. Klien dekat dengan kakek dan neneknya karena rumah mereka bersebelahan dan klien seringkali membantu kedua orang tua ayahnya tersebut. Hubungan kedekatan ini dapat dilihat dari penuturan klien bahwa kakeknya sering mengajak klien ikut keliling desa saat tahun baruan karena kakeknya tidak ingin klien melakukan hal yang tidak baik. Selain itu, kakek dan neneknya pun sering mengunjungi klien di LPKA.

Klien juga mengaku dekat dengan adik perempuan dari ayahnya karena memiliki usia yang sama, sehingga mereka sering bermain bersama. Lalu klien juga dekat dengan uwanya yang merupakan anak kedelapan kakak dari ibunya. Klien dekat dengan uwanya karena saat kecil sehari-hari klien dititipkan ke rumah uwanya karena ibu klien harus bekerja menjaga warung.

Hubungan klien dengan temannya sangat baik dan ikut mempengaruhi diri klien. Klien mengaku bahwa ia pernah bertengkar hebat dengan orang lain hingga melakukan kekerasan fisik untuk membela temannya. Rasa solidaritas klien terhadap temannya ikut berpengaruh pada kondisi emosi klien. Klien yang memiliki sifat emosional menjadi bertambah emosi ketika temannya disakiti oleh orang lain dan klien pun tidak segan untuk melakukan perlawanan pada orang lain yang menyakiti temannya bahkan klien tidak segan untuk melakukan tindakan kekerasan demi untuk membela temannya.

Klien memiliki dua orang teman yang sangat dekat dan sangat mengenal klien lebih dari teman-temannya yang lain. Menurut klien, yang dikatakan teman adalah seseorang yang selalu ada di kala susah dan senang. Sekarang, saat klien tinggal di LPKA, klien masih sering dikunjungi oleh temannya dan klien merasa senang karena temannya tidak ada yang meninggalkannya saat ia mengalami kesulitan.

Hubungan klien dengan lingkungan di LPKA juga cukup baik. Klien mengaku mudah beradaptasi dengan lingkungan barunya. Klien juga banyak mengenal anak-anak yang ada di LPKA. Di LPKA klien memiliki dua orang teman dekat, yaitu D dan E. Teman klien D dan E menjadi tempat untuk mencurahkan isi hati klien saat berada di LPKA karena mereka satu kamar dan D sama-sama menghadapi kasus yang sama, sehingga dekat sejak dari masa persidangan. Klien seringkali jengkel dan marah kepada temantemannya di LPKA, yaitu jika ada temannya yang tidak menjalankan tugas yang diberikan oleh petugas LPKA bersama-sama.

Klien saat ini sudah memiliki pacar. Hubungan klien dengan pacarnya berjalan dengan baik. Klien sudah berpacaran selama 4 tahun. Klien mengaku bahwa ia sudah dekat dengan keluarga pacarnya, begitu pun sebaliknya. Pacarnya masih sering mengunjungi klien di LPKA. Klien beberapa kali ingin memutuskan pacarnya saat tinggal di LPKA. Namun, pacarnya masih tetap ingin melanjutkan hubungan mereka dan masih terus 


\begin{tabular}{|c|c|c|c|c|}
\hline $\begin{array}{c}\text { Focus: Jurnal } \\
\text { Pekerjaan Sosial }\end{array}$ & ISSN: $2620-3367$ & Vol. 2 No: 2 & Hal: $219-231$ & Desember 2019 \\
\hline
\end{tabular}

mendukung klien dengan keadaannya sebagai narapidana saat ini.
Berbagai hubungan yang dimiliki klien yang telah dijabarkan di atas dapat digambarkan seperti yang tertuang pada gambar 2 di bawah ini:

Gambar 2

Ecomap Klien

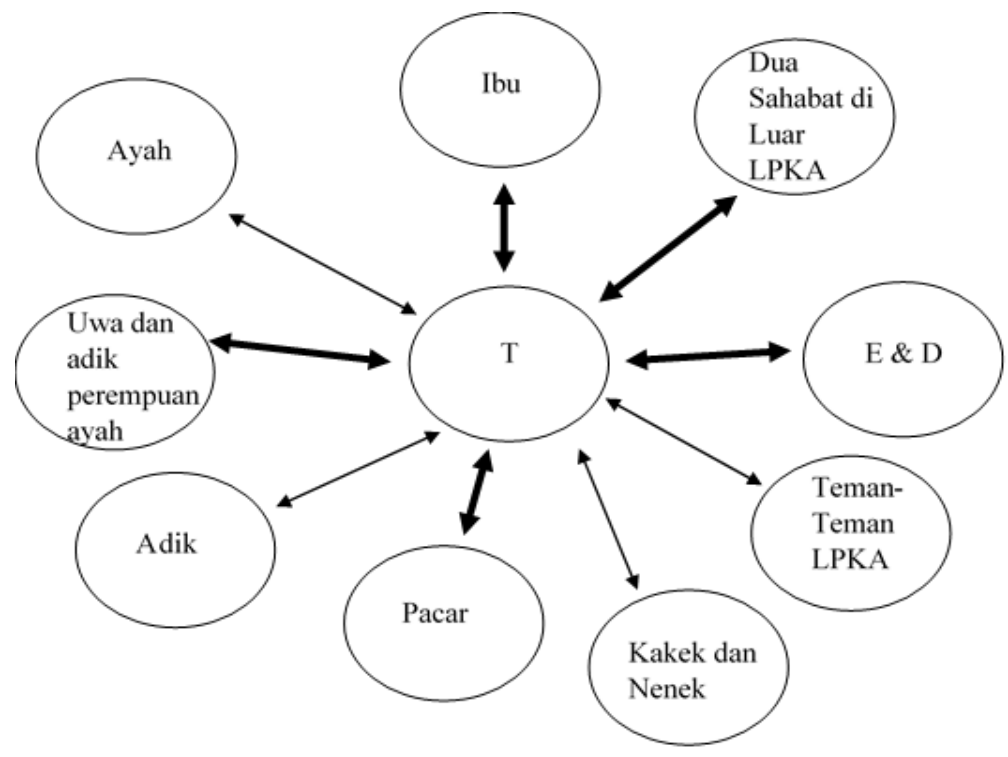

Sumber: Praktikum Pekerjaan Sosial dengan Individu dan Pengembangan Diri, 2019

Dari hasil assessment juga didapatkan bahwa klien merasa dia mulai sangat emosi saat dirinya masih duduk di bangku SMP. Klien merupakan korban bullying saat SMP. Dalam situasi itu, klien sudah tidak dapat menahan amarahnya dan akhirnya ia pun melawan pelaku bullying tersebut. Dari kejadian itulah korban menjadi seorang yang emosional sampai saat ini. Saat itu cara klien meredakan emosinya adalah dengan tidur dan menulis. Klien memiliki kesenangan menulis, sehingga cara tersebut digunakannya untuk meluapkan emosi. Selain itu jika klien marah dengan temannya, klien akan langsung mengatakan kepada temannya bahwa dirinya marah dan menegurnya.

Kondisi saat ini, klien mengungkapkan bahwa perlakuan teman-temannya di LPKA membuatnya kurang nyaman. Saat klien menghampiri temannya yang sedang bercanda, temannya langsung diam. Selain itu, klien merasa bahwa teman-temannya menganggap klien adalah orang yang memiliki power, sedangkan klien sendiri merasa bahwa dirinya tidak sama sekali memiliki power. Klien mengatakan begitu karena klien selalu dihormati dan di beri kesempatan lebih dulu oleh teman-temannya saat melakukan sesuatu. Seperti saat sedang dibagikan makanan, teman-temannya langsung memberikan makanan tersebut kepada klien, sedangkan perlakukan teman-temannya pada andikpas lainnya tidak demikian.

Klien merasa ada sesuatu yang janggal dan sangat ingin mengetahui alasan temantemannya memperlakukan diri klien seperti itu. Klien pernah bertanya kepada temannya, namun temannya selalu menolak untuk menjawab dengan jujur. Rasa keinginantahuannya mendorong klien meminta tolong kepada teman baiknya untuk menanyakan alasan mengapa teman-teman memperlakukan klien seperti itu. Jawabannya adalah karena mereka takut serta khawatir jika klien marah karena mengetahui bahwa sebelumnya klien sering menggunakan kekerasan fisik saat dirinya sedang marah atau merasa emosi. Klien mengaku dirinya sudah pernah memberitahukan temannya bahwa sekarang ia 


\begin{tabular}{|c|c|c|c|c|}
\hline $\begin{array}{c}\text { Focus: Jurnal } \\
\text { Pekerjaan Sosial }\end{array}$ & ISSN: $2620-3367$ & Vol. 2 No: 2 & Hal: $219-231$ & Desember 2019 \\
\hline
\end{tabular}

tidak akan seperti itu lagi saat marah, namun teman-temannya masih saja tidak berubah.

Praktikan juga mengamati perilaku klien saat melakukan assessment. Ada satu kejadian di mana perubahan emosi klien yang berlangsung cepat dapat dilihat oleh praktikan. Klien terlihat tidak suka saat temannya dibohongi oleh orang lain. Kejadiannya bermula saat praktikan, klien serta 3 andikpas lainnya sedang bermain games. Di awal kegiatan, semuanya berjalan dengan baik sampai suatu saat ada salah satu orang andikpas yang membohongi teman dekat klien (bersikap curang).

Dalam situasi demikian, tampak ada perubahan raut wajah pada diri klien saat teman dekatnya dibohongi. Klien berubah menjadi sinis kepada temannya tersebut. Awalnya raut wajahnya senang kemudian berubah menjadi raut wajah yang menandakan dirinya kesal saat kejadian itu terjadi.

\section{Plan of Treatment (POT)}

Hasil assessment menunjukkan bahwa klien memiliki permasalahan terkait pengendalian emosi, yaitu sebagai berikut:

a. Sulit mengendalikan emosi jika orang terdekat disakiti. Klien merasa dirinya harus terlibat dalam masalah yang dialami oleh orang terdekatnya dengan orang lain. Saat emosi seringkali klien bertindak dengan cepat tanpa berpikir panjang mengenai akibat yang akan diterimanya, misalkan saat melawan orang lain yang menyakiti temannya.

b. Hal-hal kecil dapat mempengaruhi emosi klien. Ketika ia tidak suka dengan hal tertentu, maka akan terjadi perubahan emosi yang cepat dalam diri klien. Contohnya saat ia bangun pagi dan teringat bahwa klien harus membereskan tempat tidur, klien akan merasa badmood dan marah-marah.

Berdasarkan hal tersebut, maka plan of treatment yang akan dilakukan adalah:

a. Tujuan: Praktikan membantu klien agar dapat memiliki pikiran alternatif yang positif saat mengalami suatu kejadian, sehingga klien mampu untuk memilih pikiran mana yang seharusnya klien pikirkan saat menghadapi permasalahan tersebut. Dalam hal ini, praktikan membantu klien membiasakan diri untuk bersikap rileks saat menghadapi permasalahan.

b. Praktikan menjelaskan kegunaan dan manfaat penggunaan kolom self-talk positive. Dalam hal ini diharapkan klien dapat memiliki pikiran alternatif yang lebih positif dalam menghadapi permasalahan ataupun situasi yang tidak nyaman bagi diri klien. Praktikan juga menjelaskan kegunaan dan manfaat dari memilih sikap rileks, yaitu agar klien dapat menghilangkan sebagian rasa emosi saat berhadapan dengan suatu permasalahan.

c. Praktikan menjelaskan proses yang akan dilakukan oleh klien dalam mengatasi permasalahan yang dihadapinya, yaitu dengan menggunakan cognitive restructuring form (CRF) yang ditujukan untuk mengubah kognisi negatif pada diri klien. Selain itu, praktikan pun menggunakan teknik deep breathing, yaitu agar klien bisa mencapai kondisi rileks saat emosinya mulai muncul. Pertama-tama praktikan mulai menjelaskan tahapan pengisian CRF kepada klien, setelah itu memberikan penugasan bagi klien untuk mengisi CRF. Praktikan juga menjelaskan langkah-langkah melakukan terapi relaksasi dengan teknik deep breathing.

d. Proses pengisian cognitive restructuring form (CRF) dilakukan oleh klien dalam waktu dua minggu. Selama proses pengisian CRF oleh klien, praktikan melakukan proses pendampingan setiap minggu dan juga untuk mengevaluasi kondisi klien.

\section{Treatment}

Berdasarkan hasil assessment dan plan of treatment, maka intervensi yang akan dilakukan praktikan terhadap klien mengenai pengendalian emosi pada klien adalah dengan menggunakan teknik rational therapy, yaitu menggunakan cognitive restructuring form (CRF) 6 kolom.

Tabel 3 berikut ini menjelaskan hasil assessment terhadap klien dengan menggunakan CRF 6 kolom, yaitu sebagai berikut: 
Tabel 3

Hasil Assessment Dengan Menggunakan Cognitive Restructuring Form (CRF) 6 Kolom

\begin{tabular}{|c|c|c|c|c|c|}
\hline $\begin{array}{c}\text { Treatment } \\
\text { ke- }\end{array}$ & $\begin{array}{c}\text { Pengalaman } \\
\text { Emosi }\end{array}$ & $\begin{array}{c}\text { Presentase } \\
(\%)\end{array}$ & Self-Talk Negative & $\begin{array}{c}\text { Self-Talk } \\
\text { Positif }\end{array}$ & $\begin{array}{c}\text { Presentase } \\
(\%)\end{array}$ \\
\hline 1 & $\begin{array}{c}\text { Bangun tidur } \\
\text { membereska } \\
\text { n tempat } \\
\text { tidur }\end{array}$ & $70 \%$ & $\begin{array}{c}\text { Saya malas } \\
\text { membereskan } \\
\text { tempat tidur saat } \\
\text { bangun pagi } \\
\text { karena } \\
\text { menyusahkan }\end{array}$ & - & - \\
\hline 2 & $\begin{array}{c}\text { Bangun tidur } \\
\text { membereska } \\
\text { n tempat } \\
\text { tidur dan } \\
\text { teringat ibu }\end{array}$ & $1 \%$ & - & $\begin{array}{c}\text { Saya tidak } \\
\text { boleh } \\
\text { emosian dan } \\
\text { malas supaya } \\
\text { mendapat } \\
\text { buku }\end{array}$ & Bahagia 20\% \\
\hline 4 & $\begin{array}{c}\text { Bangun tidur } \\
\text { lesu }\end{array}$ & Marah 20\% & $\begin{array}{c}\text { Saya emosi } \\
\text { karena lelah } \\
\text { membereskan } \\
\text { kamar hanya } \\
\text { bertiga }\end{array}$ & $\begin{array}{c}\text { Saya tidak } \\
\text { boleh emosi } \\
\text { supaya } \\
\text { mendapat } \\
\text { buku }\end{array}$ & Bahagia $50 \%$ \\
\hline 5 & $\begin{array}{c}\text { Bangun tidur } \\
\text { ngedumel }\end{array}$ & Marah $50 \%$ & $\begin{array}{c}\text { Saya badmood } \\
\text { bangun kesiangan }\end{array}$ & - & \\
\hline
\end{tabular}

Sumber: Praktikum Pekerjaan Sosial dengan Individu dan Pengembangan Diri, 2019

Berdasarkan data yang tertuang dalam tabel 3 tersebut, terlihat bahwa klien masih kesulitan dalam menentukan self-talk positive. Klien masih belum aktif terlibat menggunakan $\mathrm{CRF}$, hal ini tampak bahwa klien hanya mengisi tabel tersebut selama lima hari. Saat pendampingan di minggu pertama, klien mengungkapkan dirinya menuliskan isi tabel di buku karena masih takut ada kekeliruan, saat itu praktikan mengevaluasi hasil dan menjelaskan kembali langkah-langkah dalam mengisi CRF dengan benar serta mengingatkan klien untuk memindahkan isi tabel dari buku tulis miliknya pada tabel CRF yang praktikan berikan.

Selain CRF, praktikan juga menggunakan metode deep breathing sesuai dengan plan of treatment. Intervensi ini digunakan untuk membuat klien berada dalam kondisi rileks saat menghadapi permasalahan yang memunculkan emosi pada diri klien, sehingga klien tidak langsung melampiaskan kekesalannya. Metode deep breathing yang digunakan adalah teknik gelembung soda, teknik ini sama dengan teknik deep breathing, namun disini klien harus membayangkan suara yang mengganggu seperti gelembung soda yang hilang dipermukaan.
Langkah pertama yang dilakukan adalah klien harus duduk senyaman mungkin dan rileks, setelah itu mata dipejamkan. Kemudian fokus pada nafasnya, klien mengambil nafas pelanpelan sedalam-dalamnya lalu dikeluarkan perlahan-lahan melalui mulut dengan mendengarkan suara paru-paru yang mengembang dan suara udara yang bergesekan. Lalu setelah diulangi beberapa kali teknik inipun selesai. Klien mengungkapkan bahwa dirinya merasa lebih rileks dan tenang setelah melakukan teknik ini.

\section{Terminasi}

Setelah melakukan intervensi dan evaluasi terhadap apa yang dilakukan oleh praktikan bersama klien selama proses pendampingan, tahapan selanjutnya adalah terminasi. Terminasi dilakukan untuk mengakhiri masa praktikum dan memastikan target minimal dari intervensi dapat tercapai. Target minimal dari praktikan dalam intervensi ini adalah klien dapat mengendalikan emosinya dengan baik dan bisa berpikir jernih sebelum melakukan suatu tindakan untuk menghadapi suatu masalah. 
Terminasi dilakukan pada hari Senin, 20 Mei 2019. Praktikan menjabarkan hasil yang sudah tercapai saat intervensi dilakukan. Klien mengaku bahwa metode deep breathing sangat berpengaruh bagi dirinya. Namun, klien mengaku masih belum begitu memahami CRF.

\section{Evaluasi}

Evaluasi dilakukan untuk menilai apakah proses pendampingan berjalan sesuai dengan rencana atau tidak. Berikut ini adalah hal-hal yang dapat diperoleh dalam proses evaluasi, yaitu:

a. Dalam proses pendampingan, klien terlibat secara aktif dan dapat dengan jujur serta terbuka dalam menceritakan informasi mengenai dirinya. Klien senang dirinya bisa menceritakan keluh kesahnya selama berada di dalam LPKA kepada praktikan. Awalnya klien masih tertutup mengenai keluhan terkait permasalahan emosialnya. Namun, setelah beberapa kali praktikan bertemu dengan klien, akhirnya klien mau untuk menceritakan banyak hal terkait kesulitannya dalam mengendalikan emosinya. Setelah dilakukan proses pendampingan, terjadi perubahan pada kondisi emosional klien, sekarang klien sudah mulai dapat mengendalikan emosinya dengan baik, tidak marah saat bangun pagi karena harus membereskan tempat tidur.

b. Klien menyatakan bahwa teknik mengendalikan emosi dengan menggunakan teknik deep breathing gelembung soda membantu dirinya dalam menciptakan ketenangan dan rileks saat emosinya mulai naik. Adapun dalam pengunaan $\mathrm{CRF}$, klien masih mengalami kesulitan.

c. Tujuan intervensi telah tercapai, klien mulai dapat mengendalikan emosinya dengan baik. Namun perlu latihan lebih banyak lagi untuk dapat mengisi tabel CRF, agar klien dapat memiliki alternatif self-talk positive.

d. Hambatan yang dihadapi oleh praktikan untuk dapat mengingatkan klien di luar jam pendampingan, karena tidak bisa menghubungi klien selain bertemu langsung.

\section{SIMPULAN DAN SARAN}

Berbagai tahapan kegiatan dalam pelaksanaan praktikum pekerjaan sosial dengan individu dan pengembangan diri ini telah dilaksanakan dari mulai kontak awal sampai terminasi. Fokus dalam proses intervensi adalah pada pribadi klien yang emosional. Klien memiliki perubahan emosi yang cepat saat menghadapi suatu kejadian yang tidak disukainya. Praktikan bersama klien berusaha dan bekerja sama untuk mengatasi permasalahan yang dihadapi klien dengan menggunakan metode intervensi rational therapy, yaitu dengan menggunakan cognitive restructuring form disertai dengan penggunaan teknik deep breathing.

Simpulan yang diperoleh dengan menggunakan metode tersebut adalah:

a. Klien memiliki pikiran positif namun klien masih menolak menggunakan pikiran tersebut saat dihadapkan pada suatu kejadian yang membuatnya emosi.

b. Klien akan dapat mengendalikan emosinya bila klien dapat menenangkan dirinya dengan melakukan relaksasi.

Berdasarkan hasil yang dicapai pada praktikum ini, maka praktikan mencoba memberi saran untuk klien antara lain:

a. Klien diharapkan berlatih dalam memilah self-talk negative dan selftalk positive saat dihadapkan pada suatu kejadian.

b. Klien diharapkan dapat mempertahankan kondisi yang tenang pada dirinya saat emosinya muncul, sehingga klien tidak cepat melampiaskan emosinya dan berdampak negatif pada orang lain.

\section{UCAPAN TERIMA KASIH}

Penulis mengucapkan terimakasih kepada pihak yang memberikan bantuan serta bimbingan sehingga penulisan laporan mikro ini dapat terselesaikan. Penulis menyampaikan terima kasih kepada:

a. Tuhan YME karena dengan pengantara dan berkat-Nya penulis bisa menyelesaikan Laporan Praktikum ini.

b. Pihak Lembaga Pembinaan Khusus Anak Bandung karena telah mengizinkan untuk menggunakan LPKA sebagai tempat 


\begin{tabular}{|c|c|c|c|c|}
\hline $\begin{array}{c}\text { Focus: Jurnal } \\
\text { Pekerjaan Sosial }\end{array}$ & ISSN: $2620-3367$ & Vol. 2 No: 2 & Hal: $219-231$ & Desember 2019 \\
\hline
\end{tabular}

melakukan praktikum mikro dan telah menyediakan klien.

c. Tim dosen pengampu mata kuliah praktikum pekerjaan sosial dengan individu dan pengembangan diri yang telah membimbing dan membantu selama proses praktikum berlangsung.

d. T.D selaku klien yang telah banyak membantu selama proses praktikum dan sudah mau terbuka serta bekerja sama dengan baik sehingga penulis bisa menyelesaikan laporan ini dengan baik.

\section{DAFTAR PUSTAKA}

Ali, M., \& Asrori, M.(2005). Psikologi Remaja Perkembangan Peserta Didik. PT. Bumi Aksara .

Arikhman, N. (n.d.). Efektivitas Deep Breathing Relaxation Techniques Menurunkan Nyeri Pasca Secatio Caesarea. Kesehatan Medika Saintika, 9.

Azmi, N. (2015). Potensi Emosi Remaja Dan Pengembangannya. Sosial Horizon : Jurnal Pendidikan Sosial, 2.

Berk, L. (2003). Child Development. Boston: Allyn and Bacon.

Efrod, B. T. (2017). 40 Teknik Yang Harus Diketahui Setiap Konselor. Yogyakarta: Pustaka Pelajar.

Fajarudin, M. V., \& Pratiwi, T. I. (2016). Penerapan Strategi Cognitive Restructuring Untuk Menurunkan Persepsi Negatif Terhadap Pelaksanaan Program Bimbingan Dan Konseling Pada Siswa Kelas X-4 Sma Negeri 1 Kaangrejo Tulungagung. Jurnal $B K, 6$.

Hurlock, E. B. (1990). Psikologi Perkembangan, Suatu Rentan Kehidupan (Terjemahan : Istiwidayanti dan Soedjarwo). Jakarta: Erlangga.

Hanifa, R., \& Santoso, M. B. (n.d.). Cognitve Restructuring Dan Deep Breathing Untuk Pengendalian Kecemasan Pada Penderita Fobia Sosial. Share : Social Work Journal, 6, 154-272.

Indramastuti, A. M. (2017). Teknik Cognitive Restructuring Untuk Mereduksi
Prokrastinisasi Akademik Peserta Didik Kelas X Sman 2 Sukoharjotahun Ajaran 2016/2017. Surakarta: Universitas Sebelas Maret.

McWhirter, J., McWhirter, B., McWhirter, E., \& McWhirter, R. (2007). At Risk Youth : A Comprehensive Response for Counselors, Teachers, Psychologists, adn Human Service Proefessionals. United States of America: Thomson Brooks/Cole.

Muawanah, L. B., \& Pratikto, H. (2012). Kematangan Emosi, Konsep Diri Dan Kenakalan Remaja. Jurnal Psikologi, 7, 490-500.

Noviandari, H., \& Kawakib, J. (2016). Teknikcognitive Restructuring Untuk Meningkatkan Selfefficacy Belajar Siswa. Jurnal Psikologi, 3, 76-86.

Nursalim, M. (2013). Strategi Intervensi dan Konseling. Jakarta: Indeks.

Rizkiawati, R., \& Siti Aisah, D. H. (n.d.). Mengatasi Masalah Distorsi Kognitif Pada Klien Usia Remaja Dengan Metode Cognitive Resturucting Form. SHARE : SOCIAL WORK, 6, 154-272.

Santoso, M. B. (2017). Remaja Berisiko. Sumedang: Niaga Muda Press.

Sarry, Y. N. (2017). Perkembangan Kognitif Dan Emosi Psikologi Masa Remaja Awal. Jurnal Pengabdian Kepada Masyarakat, 1, 6-12.

Sawrono. (2011). Psikologi Remaja. Jakarta: PT.Rajawali Pers.

Susanti, Y., Pamela, E. M., \& Haryanti, D. (n.d.). Gambaran Perkembangan Mental Emosional Pada Remaja.

Suwardianto, H., \& Kurnia, E. (2011). Pengaruh Terapi Relaksasi Napas Dalam (Deep Breathing) Terhadap Perubahan Tekanan Darah Pada Penderita Hipertensi Di Puskesmas Kota Wilayah Selatan Kota Kediri. JURNAL STIKES RS BAPTIS, 4.

Unknown. (n.d.). Retrieved from http://repo.iaintulungagung.ac.id/6991/5/BAB\%20II.pdf

Zahara, D., \& Fadhlia, T. N. (2013). Pengaruh Kematangan Emosi Pada Remaja Ditinjau Dari Pola Asuh Orang Tua Dan Jenis Kelamin. An-Nafs, 8. 